Barbara Pytko, Roman Watras

Akademia Morska w Gdyni

\title{
Polska przedsiębiorczość w gospodarce morskiej - problemy i szanse na sukces
}

\section{Wprowadzenie}

Celem niniejszego artykułu jest przybliżenie sytuacji przedsiębiorstw polskiej gospodarki morskiej oraz określenie stanu ich aktywności, przedsiębiorczości i postaw innowacyjnych. Rodzi się pytanie: czy obecnie w tym sektorze można w ogóle dostrzec organizacje przedsiębiorcze lub działania o charakterze przedsiębiorczym?

Przedsiębiorstwa gospodarki morskiej to głównie organizatorzy żeglugi morskiej, przedsiębiorstwa rybołówstwa morskiego, porty morskie, stocznie i wiele małych firm kooperujących z obsługa portów i stoczni. Większość z nich to organizacje o dość skomplikowanym profilu działalności, dużej kapitałochłonności i silnej konkurencji światowej. Ponadto, okres transformacji ustrojowej i wprowadzenie reform gospodarczych w Polsce w tym sektorze nie sprzyjały rozwojowi tych przedsiębiorstw. Oznaczało to niszczenie floty, przemysłu okrętowego oraz jego zaplecza ${ }^{1}$. Utrwalono także przekonanie, że znaczenie morza dla gospodarki narodowej jest ograniczone, a zatem flota morska i przemysł okrętowy są nieopłacalne, cała zaś gospodarka morska jest balastem hamującym rozwój gospodarki całego kraju. Na szczęście okres ten już minął, zarysowały się bowiem pomyślne trendy światowe w obrocie morskim oraz koniunktura na transport morski, budowę nowych statków i remonty stoczniowe.

\section{Wpływ transformacji ustrojowej na stan przedsiębiorstw gospodarki morskiej}

Gospodarczy rozwój danego regionu i całego kraju determinowany jest różnymi czynnikami z zakresu działalności politycznej, legislacyjnej i gospodarczej państwa. Powiązany jest również z uwarunkowaniami zewnętrznymi - prawem międzynarodowym, trendami i koniunkturą w gospodarkach światowych.

Sprawny rozwój przedsiębiorstw i wyzwolenie postaw przedsiębiorczych w kraju można niewątpliwie osiagnąć wówczas, gdy władze centralne i lokalne są w pełni świadome istoty warunków ułatwienia działalności przedsiębiorstw. Przedsiębiorstwom gospodarki morskiej w Polsce nie tylko nie ułatwiono działalności, ale zastosowano wobec nich terapię szokową, gwałtowną i nieprzemyślaną, hamującą ich rozwój na wiele lat. Zastosowanie najskuteczniejszych instrumentów: ustawodawstwa i stosunku władz fiskalnych, niesprzyjających przedsiębiorczości tego sektora, a także brak polityki morskiej, strategii konkurowania oraz kapitałów własnych dopełniły obraz trudnej sytuacji tych przedsiębiorstw i upadku wielu z nich.

Warunki ekonomiczne są nadal niedostosowane do potrzeb tych przedsiębiorstw. Brak im środków na prowadzenie inwestycji odtworzeniowych i rozwojowych, na spłatę długów z zaciągniętych

${ }^{1}$ J.W. Doerffer, Powiqzania gospodarki morskiej z gospodarkq narodowa [w:] Materiaty konferencji „,Strategia rozwoju gospodarki morskiej”, Gdańsk, 23.04.1995 r. 
kredytów. Inicjatywy menedżerskie pozwalają niektórym przedsiębiorstwom utrzymać się na rynku, ale bez zdolności konkurowania z najlepszymi.

Przedsiębiorstwa przemysłu okrętowego podejmują ogromne wyzwania przyszłości. Jednakże w warunkach nierozwiązanych płatności z okresu przeszłego, w warunkach koniecznych przekształceń własnościowych i restrukturyzacji nie są one w stanie sprostać konkurencji na wspomaganym przez rządy międzynarodowym rynku okrętowym.

Światowa gospodarka morska zna i stosuje różne formy finansowego wspierania przedsiębiorstw morskich ${ }^{2}$ :

- długoterminowe nisko oprocentowane pożyczki (Japoński Bank Rozwoju);

- udzielanie wspieranych przez rząd kredytów dla stoczni (Japonia);

- wykorzystywanie systemu podatkowego dla poprawy konkurencyjności (Dania).

Zastosowanie podobnych rozwiązań w Polsce pomogłoby polskiemu przemysłowi morskiemu ponownie stać się konkurencyjnym.

W krajach Unii Europejskiej nie ma polityki branżowej, np. polityki morskiej. Tymczasem istniał ukryty protekcjonizm państw Unii dla gospodarki morskiej, który nabiera cech formalnej polityki morskiej ${ }^{3}$. Obserwuje się większe zainteresowanie rządu i zaangażowanie w wypracowywanie programów naprawczych. Programy naprawcze i podejmowanie restrukturyzacji przedsiębiorstw gospodarki morskiej, chociaż powolne, często postępujące „od dołu”, zmierzają jednak do racjonalizacji działań, wzmocnienia kapitałowego części przedsiębiorstw i uzyskania w miarę trwałej zdolności finansowej. Te przedsiębiorstwa to żegluga promowa, nieliczne żeglugowe spółki armatorskie, porty morskie Gdańsk, Gdynia, Szczecin-Świnoujście oraz stocznie remontowe wraz z nowym, odbudowanym zapleczem kooperacyjnym.

\section{Stan obecny przedsiębiorstw gospodarki morskiej i cechy przedsiębiorcze}

Prezentując rzeczywistość przedsiębiorstw gospodarki morskiej w Polsce, nie należy opisywać ich tylko w czarnych barwach, są bowiem wśród nich także organizacje przedsiębiorcze. Polskie stocznie więcej budują i remontują porty przeładowują więcej ładunków, flota nieco się powiększa i nawet polskie rybołówstwo odnotowuje poprawę 4 .

Tendencje wzrostu i poprawy są również związane z działaniami przedsiębiorczymi, przeważającymi w dwóch płaszczyznach:

- w zakresie modernizacji, nowych inwestycji i rozwoju infrastruktury;

- w zakresie działalności menedżerskiej i efektów przedsiębiorstw morskich.

Modernizacja, nowe inwestycje i rozwój infrastruktury portów, stoczni, tras dojazdowych (morskich, drogowych i kolejowych) mają związek z wykorzystywaniem unijnych funduszy strukturalnych oraz kapitału nowych właścicieli tych przedsiębiorstw. Do wykazania się przedsiębiorczością niezbędny jest kapitał. W sektorze morskim w pozyskiwaniu tego kapitału powinno mieć udział państwo. Dopiero wówczas, kiedy dysponuje się kapitałem, można być przedsiębiorczym w pełnym zakresie - wprowadzać innowacyjne produkty i usługi, inwestować w rozwój, zatrudniać najlepiej wykwalifikowanych pracowników oraz poszukiwać nowoczesnych metod organizacji i zarządzania.

\footnotetext{
${ }^{2}$ S. Piocha, Gospodarka morska. Ekonomiczne właściwości funkcjonowania i rozwoju, Wyższa Szkoła Inżynierska, Koszalin 1996, s. 121.

${ }^{3}$ J. Pietrusińska, Światowy Dzień Morza [w:] „Porty i Spedycja”, 5/2005, s. 9.

${ }^{4}$ P. Witek, Raport GUS o gospodarce morskiej w 2004 roku. Morze statystyki [w:] „Budownictwo Okrętowe", 4/2005, s. 15-17.
} 
Największe zaangażowanie kapitałowe i największe ożywienie dotyczy dziś:

- portów Gdańska i Gdyni w zakresie budowy nowych terminali kontenerowych;

- modernizacji nabrzeży, inwestycji w urządzenia przeładunkowe i ochronę środowiska;

- stoczni remontowych w zakresie zakupu nowych technologii dla procesów diagnostycznych i projektowania budowy oraz remontów statków.

Sprzyja temu utrzymywanie się koniunktury światowej na przewozy kontenerowe, przewozy paliw płynnych i remonty statków. Ożywienie widoczne jest w polskich portach, np. w porcie gdyńskim (tab.1).

Tab. 1. Przeładunki w Porcie Gdynia

\begin{tabular}{|l|c|c|c|}
\hline \multicolumn{1}{|c|}{ Ladunek } & $\begin{array}{c}\text { Styczeń - sierpień } \\
\mathbf{2 0 0 4}\end{array}$ & $\begin{array}{c}\text { Styczeń - sierpień } \\
\mathbf{2 0 0 5}\end{array}$ & Dynamika (w \%) \\
\hline Węgiel i koks & 743500 & 720000 & 97 \\
\hline Rudy & 700 & 0 & 0 \\
\hline Inne masowe & 1184200 & 1202200 & 102 \\
\hline Zboża i pasze & 733500 & 871300 & 119 \\
\hline Drewno & 57500 & 48100 & 84 \\
\hline Drobnica & 5099000 & 5591400 & 110 \\
\hline Paliwa płynne & 86700 & 288300 & 333 \\
\hline Razem & $\mathbf{7 9 0 5 1 0 0}$ & $\mathbf{8 7 2 1 ~ 3 0 0}$ & $\mathbf{1 1 0}$ \\
\hline Kontenery & 280307 & 300004 & 107 \\
\hline
\end{tabular}

Źródło: Przeładunki Portu Gdynia po III kw. 2005 r., „Porty i Spedycja”, 5/2005, s. 3.

Największą dynamikę wzrostu wykazują przeładunki paliw płynnych, zbóż i pasz, drobnicy oraz kontenerów. Bałtycki Terminal Kontenerowy usytuowany w Porcie Gdynia przeładowuje $80 \%$ kontenerów docierających do Polski i wysyłanych z Polski. Korzystają z niego najwięksi armatorzy świata ${ }^{5}$. Budowany jest w nim także drugi terminal kontenerowy (Hutchison Port Holdings), który wkrótce zamierza rozpocząć działalność eksploatacyjną.

Podobna tendencja występuje w Porcie Północnym (Gdańsk), gdzie odnotowuje się znaczny wzrost przeładunków paliw płynnych i węgla. Od końca maja do końca września 2005 r. dwukrotnie wzrosły rentowność i zysk.

Menedżerowie Portu Północnego poszukują nowych obszarów działalności, gdyż nie zamierzają poprzestać na przeładunkach paliw i węgla. Planują także rozpoczęcie budowy nowego terminalu kontenerowego. Działania te wiążą się z opracowaniem planów, budową lub przebudową nabrzeży, budową całej infrastruktury otoczenia, a to wyzwala zaangażowanie innych firm pracujących na rzecz nowych inwestycji w gospodarce morskiej. Te małe firmy o profilu morskim wykazują przedsiębiorczość w przygotowywanych aplikacjach przetargowych, projektach własnych i udziale w ich realizacji.

Zwiększenie zdolności przeładunkowych nie byłoby możliwe bez inwestycji w urządzenia przeładunkowe - suwnice, urządzenia do obsługi wagonów z kontenerami czy rozwiązania techniczne w zakresie sprzętu do wyładunku i przeładunku towarów. Najwięcej ładunków przeładowano w porcie Gdańsk - 75\% ogólnego obrotu tych towarów w Polsce.

${ }^{5}$ M. Grzybowski, Dynamiczny terminal [w:] „Porty i Spedycja”, 2/2005, s. 12 i 13. 
Rozrost tej działalności nie może się odbywać kosztem środowiska przyrodniczego. Realizuje się duże inwestycje w ochronę środowiska morskiego i redukcję zanieczyszczeń atmosfery.

Najbardziej widoczną cechą przedsiębiorczą jest dążenie do zapewnienia, aby porty polskie i stocznie były ekologicznie czyste. Podejmowane działania to:

- monitorowanie stanu powietrza;

- przebudowa kanalizacji portowych;

- modernizacja stacji uzdatniania wody;

- badania czystości osadów dennych w basenach portowych;

- wprowadzenie hermetycznego system przeładunku chemikaliów;

- poprawa systemu odbioru i unieszkodliwiania odpadów;

- budowa instalacji do odzyskiwania oparów węglowodorowych powstałych w czasie załadunku zbiornikowców.

Polskie stocznie odnotowują również wzrost produkcji; portfel zamówień w końcu 2004 r. był pięciokrotnie większy od produkcji 2004 r. mierzonej nośnością statków6

Produkcja stoczniowa jest bardzo złożoną sfera; przestój w tej branży to duża strata. W polskich stoczniach przestoje również występują - powodowane brakiem dopływu kapitału, mimo ograniczonego dofinansowania przez rząd. Ponadto działania banków blokują możliwość zaciągania kredytów przez stocznie. Banki uznają budowę statków za przedsięwzięcia ryzykowne pod względem finansowym (szybsza stopa zwrotu z zainwestowanego kapitału dla banków to przemysł naftowy i elektroniczny).

Statki są poszukiwanym wyrobem na rynkach międzynarodowych, ale w Polsce ich budowa nadal odbywa się w trudnych warunkach organizacyjnych i ograniczane są zdolności produkcyjne. Bardziej widoczne efekty odnotowują mniejsze stocznie remontowe, często prywatne, o stabilnej już sytuacji finansowej.

Żegluga jest traktowana jako margines polityki transportowej. Wprowadzenie gospodarki rynkowej spowodowało odcięcie żeglugi od źródeł tanich kredytów. Przedsiębiorstwa zadłużyły się, nie mają pieniędzy na spłatę długów oraz na inwestycje odtworzeniowe stanu floty, i utraciły zdolność konkurowania. Armatorzy podejmują różne działania: tworzą spółki zagraniczne, przerejestrowują statki pod tanie bandery, uciekając w ten sposób od polskich przepisów finansowych $^{7}$. Pod polską banderą pływa 12 jednostek; ich średni wiek w końcu 2004 r. to 30 lat. W najlepszej kondycji jest przedsiębiorstwo Polska Żegluga Morska. Jest znanym na świecie armatorem, w dobrej sytuacji finansowej. Armator myśli o nowych inwestycjach. PŻM przeszła jednak bardzo głęboki i bolesny proces restrukturyzacji organizacyjnej, kadrowej i finansowej. Sprzedano majątek nieproduktywny, który przynosił straty, ograniczono zatrudnienie. Utrzymano jednak renomę firmy, kojarzoną na świecie z wysokimi kwalifikacjami polskich marynarzy. Przedsiębiorstwo nadal jednak poszukuje drogi prywatyzacji.

Rybołówstwo morskie, jako marginalna dziedzina gospodarki morskiej, wręcz zapomniana, ograniczana limitami połowowymi i restrykcyjną polityką finansową, w 2004 r. odnotowało wzrost połowów w porównaniu z 2003 r., ale liczebność floty jest bardzo mała. Wiele statków wycofano ze względu na wiek, nieopłacalność remontów i kurczenie się łowisk przeznaczonych dla polskich statków. Cały łańcuch: połowów - przetwórstwa - odbioru na ląd - hurtowników i konsumentów, został zniszczony. Jego ograniczone ogniwa funkcjonują jako działalność marginalna.

${ }^{6}$ P. Witek, Raport GUS o gospodarce morskiej w 2004 roku. Morze statystyki [w:] „Budownictwo Okrętowe", 4/2005, s. 16

${ }^{7}$ J.W. Doerffer, Powiqzania gospodarki morskiej z gospodarka narodowa [w:] Materiaty konferencji „Strategia rozwoju gospodarki morskiej”, Gdańsk 23.04.1995 r., s. 3. 
W świetle zarysowanego skrótowo stanu gospodarki morskiej w Polsce, w trudnej i skomplikowanej sytuacji politycznej, finansowej, praw własności, restrukturyzacji i programów naprawczych, można znaleźć rozwiązania optymistyczne.

\section{Strategie przedsiębiorczości i postawy kreatywne}

W polityce Unii Europejskiej dopiero obecnie uznaje się za priorytet rozwój systemu transportowego z uwzględnieniem wymiany towarowej drogą morską. Podkreśla się przy tym, że konkurencyjność Unii w warunkach globalizacji gospodarczej zależy także od systemu portowego i całej infrastruktury morskiej państw Unii. Opracowuje się wiele dokumentów regulujących sprawy związane z tym obszarem działalności, łącznie z poszukiwaniem źródeł finansowania rozwoju tak kosztownej infrastruktury ${ }^{8}$.

Polskie przedsiębiorstwa gospodarki morskiej, szczególnie te, które mają uregulowany stan własności i dysponują własnymi kapitałami, wykazują dużą dynamikę dostosowania do konkurencji na świecie. Nie są absorbowane działaniami naprawczymi czy poszukiwaniem kapitałów na działalność. W takich warunkach można realizować strategie przedsiębiorcze, budować kulturę organizacji, doskonalić i poszukiwać innowacji w celu uzyskania przewagi na rynku. W gospodarce morskiej można wyodrębnić strategie przedsiębiorcze w dwóch obszarach (ryc. 1).

Ryc. 1. Obszar realizacji strategii przedsiębiorczych w gospodarce morskiej

\begin{tabular}{|l|l|}
\hline $\begin{array}{l}\text { Porty morskie } \\
\text { Żegluga morska } \\
\text { Stocznie } \\
\text { - Przekształcenia własnościowe } \\
\text { - Odbudowa infrastruktury } \\
\text { - Programy naprawcze } \\
\text { - Poszukiwanie źródeł finansowania }\end{array} \mid \begin{array}{l}\text { Przedsiębiorstwa prywatne wydzielone } \\
\text { z majątku portów } \\
\text { Stocznie remontowe } \\
\text { - Planowanie strategii działania } \\
\text { - Określanie celów konkurencyjności } \\
\text { - Innowacje technologiczne } \\
\text { - Metody doskonalenia jakości } \\
\text { - Aktywne zarządzanie personelem } \\
\text { - Budowa renomy marki } \\
\text { - Współpraca z otoczeniem }\end{array}$ \\
\hline
\end{tabular}

Źródło: opracowanie własne

Przedsiębiorstwa pierwszego obszaru na pewno odbudują swój majątek w taki sposób, by móc odzyskać pozycję sprzed lat, co pozwoli na bardziej aktywne, konkurencyjne działania organizacyjne i produkcyjne. Rodzi się ku temu przychylność rządu polskiego i Unii Europejskiej. Obecna koniunktura na nowe statki, na przewozy ładunków drogą morską jest tak dobra, że należy wykazywać optymizm, zwłaszcza wobec rozpoczynania budowy autostrady A1 łączącej porty morskie z południem Polski i Europy.

Przedsiębiorstwa drugiego obszaru - terminale kontenerowe i stocznie remontowe - przeżywają tak duże zapotrzebowanie na swoje usługi, że pracują z zyskiem, rozwijają się i inwestują w odtworzenie majątku. Największymi liderami przedsiębiorczości są stocznie remontowe: Stocznia

${ }^{8}$ L. Kuźma, Ekonomika portów morskich i polityka portowa, UG, Gdańsk 2003, s. 293-301. 
Remontowa „Nauta” oraz Gdańska Stocznia Remontowa. Szczególnie Gdańska Stocznia Remontowa o renomie światowej jest liderem przedsiębiorczości w polskiej gospodarce morskiej. Atuty przedsiębiorczości tej stoczni zestawiono w tab. 2 .

Tab. 2. Atuty przedsiębiorczości Gdańskiej Stoczni Remontowej

\begin{tabular}{|l|l|}
\hline \multicolumn{1}{|c|}{$\begin{array}{c}\text { Obszary zaangażowania } \\
\text { przedsiębiorczego }\end{array}$} & \multicolumn{1}{c|}{ Formy przedsiębiorczości } \\
\hline Organizacja przedsiębiorstwa & $\begin{array}{l}\text { Stocznia pracuje w ramach Korporacji „Grupa Remontowa”, struktu- } \\
\text { ra procesowa, zespoły zadaniowe. }\end{array}$ \\
\hline Kapitał i efekty ekonomiczne & $\begin{array}{l}\text { Pozyskanie kapitału prywatnego, bieżące finansowanie, corocznie wy- } \\
\text { pracowywany zysk, wysoka rentownośc. }\end{array}$ \\
\hline Produkt/usługa & $\begin{array}{l}\text { Najbardziej skomplikowane technicznie przebudowy i odbudowy } \\
\text { oraz budowa statków. }\end{array}$ \\
\hline Innowacje & $\begin{array}{l}\text { Podejmowanie eksperymentów i prac nietypowych oraz budowy stat- } \\
\text { ków specjalnych - prototypów, przygotowania do budowy kontene- } \\
\text { rowców. }\end{array}$ \\
\hline Inwestycje & $\begin{array}{l}\text { Nowoczesne formy komunikowania i programy komputerowe do sy- } \\
\text { mulacji zakresu remontu, kamery wizyjne do oceny technicznej i za- } \\
\text { kresu remontów, urządzenia laserowe do badań kadłubów. }\end{array}$ \\
\hline Metody zarządzania & $\begin{array}{l}\text { Marketing personalny, zarządzanie projektami, czystość produkcji, } \\
\text { zarządzanie jakością, przewidywanie i eliminowanie zakłóceń, ciagła } \\
\text { ocena i doskonalenie stoczni. }\end{array}$ \\
\hline Kultura organizacji & $\begin{array}{l}\text { Postawy etyczne, dbałość o klienta i pracownika, partnerska współ- } \\
\text { praca z dostawcami i kooperantami, wspieranie kultury, współpraca } \\
\text { naukowa z uczelniami wyższymi. }\end{array}$ \\
\hline Renoma firmy & $\begin{array}{l}\text { Pozycja pierwsza stoczni remontowej w Europie i siódma na świecie, } \\
\text { największy pracodawca w tej branży. }\end{array}$ \\
\hline $\begin{array}{l}\text { Każdy pracownik w łańcuchu usługi jest klientem jeden dla drugiego } \\
\text { tzw. klient wewnętrzny); badania osobowości i wspieranie ścieżki ka- } \\
\text { riery, grupy zadaniowe, aktywizacja menedżerów jako pojedynczych } \\
\text { przedsiębiorców w stoczni, przedsiębiorczość wynagradzana dodatko- } \\
\text { wo, możliwość aktywnego uczestnictwa wszystkich pracowników. }\end{array}$ \\
\hline
\end{tabular}

Źródło: opracowanie własne na podstawie: G. Landowski, Czas na zmiany [w:] „Budownictwo Okrętowe”, 8/2005, s. $16-18$.

\section{Podsumowanie}

Innowacyjne i twórcze podejście do organizacji działań odbudowujących przedsiębiorstwa gospodarki morskiej istnieje; najczęściej jest widoczne w postawach „od dołu”. Pokonanie trudności w tych organizacjach i wykorzystanie szans dla Polski musi zostać wsparte aktywnym i jednoznacznym stanowiskiem polskich władz. Z boomu na rozwój gospodarki morskiej korzystać będą także przyszłe pokolenia. Najlepsze zaś wzorce przedsiębiorczości powinny być powielane, tak by budować postawy kreatywne i sprzyjać rozwojowi Polski. 


\section{Literatura}

1. Doerffer J. W., Powiqzania gospodarki morskiej z gospodarka narodowa [w:] Materiaty konferencji „Strategia rozwoju gospodarki morskiej”, Gdańsk 23.04.1995 r.

2. Grzybowski M., Dynamiczny terminal [w:] „,Porty i Spedycja”, 2/2005.

3. Kuźma L., Ekonomika portów morskich i polityka portowa, UG, Gdańsk 2003.

4. Landowski G., Czas na zmiany [w:] „Budownictwo Okrętowe”, 8/2005.

5. Pietrusińska J., Światowy Dzień Morza [w:] „Porty i Spedycja”, 5/2005.

6. Piocha S., Gospodarka morska. Ekonomiczne właściwości funkcjonowania i rozwoju, Wyższa Szkoła Inżynierska, Koszalin 1996.

7. Przeładunki Portu Gdynia po III kw. 2005 roku [w:] „,Porty i Spedycja”, 5/2005.

8. Witek P., Raport GUS o gospodarce morskiej w 2004 roku. Morze statystyki [w:] „Budownictwo Okrętowe", 4/2005.

\section{Polish Entrepreneurship in the Naval Industry}

The goal of this text is to focus on the situation of companies in Polish naval industry and to define the condition of their activity, entrepreneurship, and their attitudes toward innovations. This discussion is a search for the answer to the question: Is it possible to see any signs of entrepreneurship in the organizations and the activities in this sector? Authors emphasize the naval companies mainly organize the sea shipping, and their business is usually complex, it needs a lot of capital, and there is fierce global competition. With the transformation of political system and Polish economical reform in this industry, it was not propitious time to growth for these companies. Both the fleet, and the shipbuilding, and their bases started to deteriorate. According to the authors, naval industry was at the disadvantage because public opinion assumed that the sea was less important to the national economy, so the fleet and shipbuilding were not economically justifiable and naval industry was the burden that slowed down the development of national economy. Fortunately this time is over, because the good trends appeared toward a growth in the naval trade, and because of boom in the sea transport, in shipbuilding and in ship maintenance. 